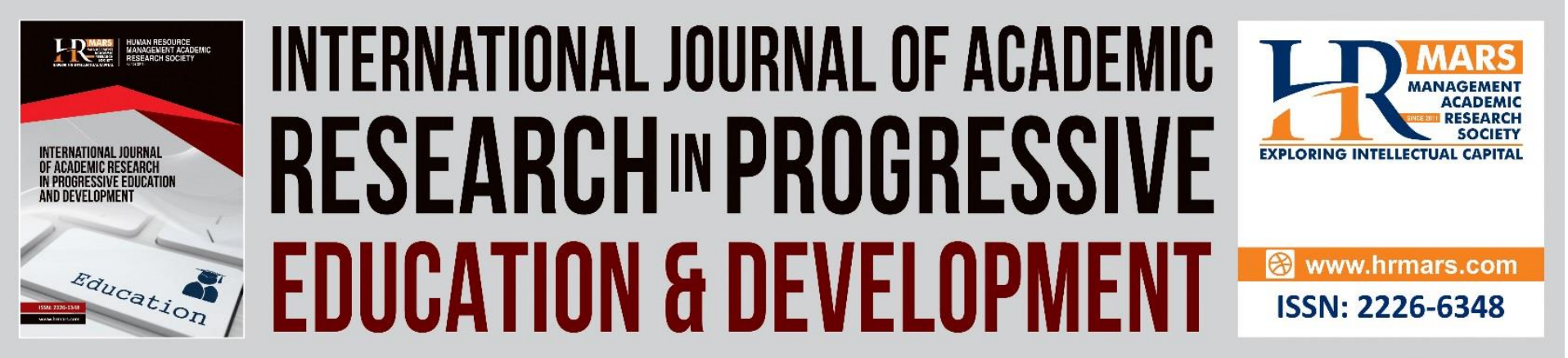

\title{
Use of Multimodality in Remote Drama Performance among Pre-Service Teachers during the Covid-19 Pandemic
}

\section{Yee Bee Choo, Aminabibi Saidalvi, Tina Abdullah}

To Link this Article: http://dx.doi.org/10.6007/IJARPED/v11-i1/12187

DOI:10.6007/IJARPED/v11-i1/12187

Received: 17 November 2021, Revised: 23 December 2021, Accepted: 06 January 2022

Published Online: 23 January 2022

In-Text Citation: (Yee et al., 2022)

To Cite this Article: Yee, B. C., Saidalvi, A., \& Abdullah, T. (2022). Use of Multimodality in Remote Drama Performance among Pre-Service Teachers during the Covid-19 Pandemic. International Journal of Academic Research in Progressive Education and Development, 11(1), 743-760.

Copyright: (C) 2022 The Author(s)

Published by Human Resource Management Academic Research Society (www.hrmars.com)

This article is published under the Creative Commons Attribution (CC BY 4.0) license. Anyone may reproduce, distribute, translate and create derivative works of this article (for both commercial and non-commercial purposes), subject to full attribution to the original publication and authors. The full terms of this license may be seen

at: http://creativecommons.org/licences/by/4.0/legalcode

Vol. 11(1) 2022, Pg. 743 - 760

http://hrmars.com/index.php/pages/detail/IJARPED

JOURNAL HOMEPAGE

Full Terms \& Conditions of access and use can be found at http://hrmars.com/index.php/pages/detail/publication-ethics 


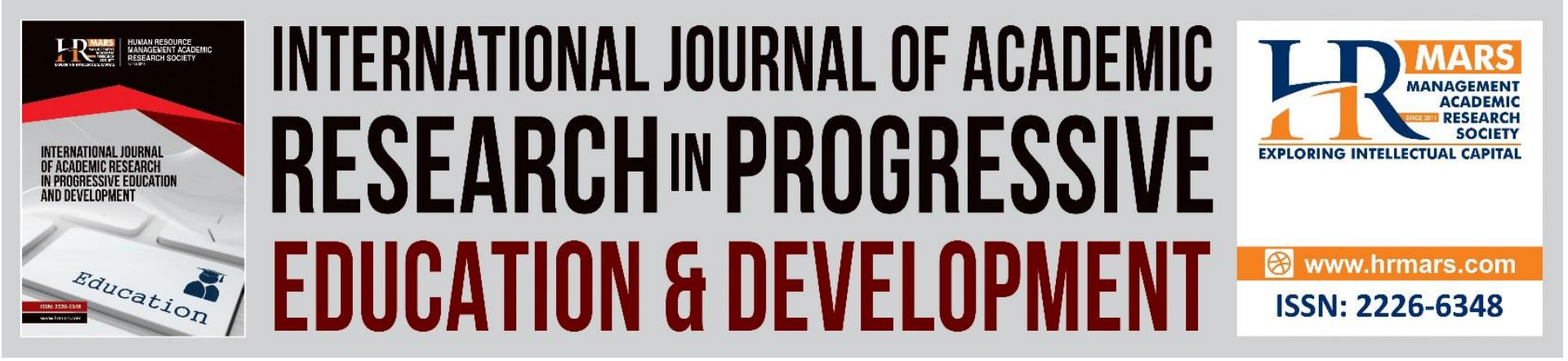

\title{
Use of Multimodality in Remote Drama Performance among Pre-Service Teachers during the Covid-19 Pandemic
}

\author{
Yee Bee $\mathrm{Choo}^{1}$, Aminabibi Saidalvi ${ }^{2}$, Tina Abdullah ${ }^{3}$ \\ ${ }^{1}$ English Language Department, Institute of Teacher Education Tun Hussein Onn Campus, \\ Malaysia, ${ }^{2}$ Academic of Language Studies, Universiti Teknologi Mara Johor, Pasir Gudang \\ Campus, Malaysia, ${ }^{3}$ Language Academy, Universiti Teknologi Malaysia, Skudai, Malaysia \\ Email: beechoo.yee@iptho.edu.my, aminabibi@uitm.edu.my, tinaabdullah@utm.my
}

\begin{abstract}
Due to the COVID-19 pandemic, the drama, which is normally performed live on stage, was changed to remote drama performance. This paper explores the use of multimodality as a pedagogical tool in a drama course among a group of 22 pre-service teachers in an institute of teacher education in Malaysia. A single case study investigated the most common modes of multimodality that students used in adapting and presenting Shakespeare's play "Macbeth" into a remote drama performance as well as their engagement in learning. Students' project output in the form of playscripts and short films were collected and analysed using a multimodal framework for analysing multimodal engagement among students. Students' reflective journals were also analysed thematically to investigate their multimodal engagement. The findings revealed the six most common multimodal modes were linguistic, visual, audio, gestural, spatial, tactile, and technical and digital. Students' multimodal engagement was also highlighted through their learning in technical and technological skills as well as cooperation. The results pave the ways for revising the course contents for the drama pedagogy through the integration of technology and more research into the use of multimodal pedagogical tools in the field of English language especially for remote drama courses.
\end{abstract}

Keywords: Multimodality, Modes of Multimodality, Multimodal Engagement, Drama Performance, Remote Drama

\section{Introduction}

Drama is a specific mode of fiction represented in performance on stage. Its representational meaning is portrayed by the playwright's messages in the script, interpreted by the readers, and performed by the actors through their stagecraft skills in speech, facial expressions, gestures, movements and actions (O'Neill, 2018). According to Nicholson (2011), the use of drama in education has long existed and signifies the idea that drama has the power to address something 'beyond itself' and is thus primarily concerned with generating new possibilities for everyday living rather than isolating drama from other elements in life. Due 
to its worth, drama has been a mandatory course for many education institutions (Ntelioglou, 2011).

Besides, drama combines speech, background music, and special sound effects with visual stimuli in the form of actions, facial expressions, and the handling of props (Kaminski, 2019). It allows students to be engaged in multimodality as they employ the images, audios, gestural, and other representational modes in the drama performance. Multimodality is an interdisciplinary approach that understands communication and representation to be more than about language and assumes that representation of all modes contribute to meaning (Bezemer, 2012). Many scholars explored the integration of multimodality into the English language teaching (Vungthong et al., 2017; Yi \& Choi, 2015; Hafner, 2015; New London Group, 1996). Although providing exposure to multiple modes of meaning is essential in English language learning, students need the meta-language to discuss and describe the modes and meanings in multimodal texts (Lim, 2018). They need to be able to critically evaluate and apply multimodal representations, and appropriate teaching and learning strategies can create multimodal engagement for students. However, many educational institutions have yet to fully tap into and develop the potential and skills that the learners possess by providing them with learning experiences that offer multimodal engagement which allows them to experience meaning making through various modes of learning (Perry, 2020) especially in a drama course.

Since the pedagogy of drama performance has recently been progressive especially with the emergence of the COVID-19 pandemic, the staging of live drama performance is transformed to remote drama performance. In some educational settings that allow the staging of live drama performance, students were required to wear masks and maintain social distance. Doing drama with limitations was difficult because face and body play vital roles in helping actors tell a story (Trujillo, 2021). At the same time, Hagan (1991) suggests that physical touch is also important for establishing relationships between actors. Performing drama remotely will make the staging process more difficult as the actors are performing individually in different locations without face-to-face meeting. Besides, it is hard for the actors to employ the stagecraft skills such as blocking and stage management as they do not perform drama on stage.

Due to the pandemic COVID-19, this case study explores the use of multimodality as a pedagogical tool in a remote drama performance. It focuses on the students' engagement with multimodality by investigating the most common modes of multimodality that they use in adapting Shakespeare's play and their learning through the remote drama performance.

Therefore, the following research questions were used in the case study:

1. What are the most common modes of multimodality that students use in remote drama performance?

2. How do students engage their learning through multimodality in the remote drama performance?

\section{Literature Review}

Drama course has the potential to extend beyond traditional forms of literacy, with its focus on both verbal and non-verbal modes of communication that makes it a mandatory course for tertiary students (Ntelioglou, 2011). Among the drama texts studied in the educational 
institutes were the plays written by William Shakespeare. His plays are widely regarded as the greatest of literature and they have been included in the drama texts for high schools and universities. Shakespeare wrote three genres in tragedy, comedy, and history and these plays are not meant to be read but to be performed on stage.

Olive (2015) discusses three approaches in learning Shakespeare: 1 ) textual (close reading of the text through translations in modern language); 2) contextual (relate the text to Shakespeare's background, cultures, and social life); and 3) active/performance (live performance on stage). In most high schools and universities, Shakespeare's texts are often studied to be performed as the final coursework assessment. In studying Shakespeare through an active or drama approach, it ensures that students develop a certain set of skills, for example, to evaluate, communicate, convey, appreciate, use, create, sustain, participate, comment and adapt (Olive, 2015). Murphy et al (2020) doubt that this approach could help learners understand Shakespeare's texts, but Luh (2019) believes that a drama approach with its components in actions, dialogues, and non-verbal language could facilitate students to actively participate in the language learning process. The student-centred process during the learning experiences precedes the drama performance and during the staging of it is where active and deep learning lies.

Drama performance allows students to express themselves as they learn to practice their stagecraft skills such as voice projection, facial expressions, gestures, body movement, and others. Costa (2016) believes that the body in movement creates sensations, impulses, and images in students that they can eventually find their way to understanding the meanings of a text. So by doing something with a text, this enables the students to read and interpret the texts more critically.

\section{Theoretical Framework Multimodality}

Drama combines speech, background music, and special sound effects with visual stimuli in the form of actions, facial expressions, and the handling of props (Kaminski, 2019). It provides a meaningful basis for the use of multiple modes of meaning-making. Multimodality attends to meaning as it is organised and configured through sets of semiotic resources for meaning making known as modes (Jewitt, 2008). Modes are different ways that texts can be presented. Image, writing, layout, speech and moving images are all examples of different kinds of modes. Cope and Kalantzis (2009a) categorise these multiple modes in written (representing meaning to oneself and others through reading and writing), oral (through speaking and listening), visual (still and moving images), audio (music, sound effects, and noises), gestural (facial expression, gestures, and body movement), spatial (layout and organisation of objects and space), and tactile (touch, smell, and taste). The written and oral modes are later combined into linguistic mode as both are related to language. Table 1 summarises the six modes of multimodality with their meanings and examples of signs and symbols. The analysis of this study is described based on this framework. 
Table 1. Modes of Multimodality

NO. MODE MEANING EXAMPLES OF SIGNS AND SYMBOLS

\begin{tabular}{|c|c|c|c|}
\hline 1 & Linguistic & $\begin{array}{l}\text { Listening, speaking, } \\
\text { reading, and writing }\end{array}$ & $\begin{array}{l}\text { Captions, headings, vocabulary, generic structure, } \\
\text { punctuation, grammar, dialogue, monologue, } \\
\text { soliloquies }\end{array}$ \\
\hline 2 & Visual & $\begin{array}{l}\text { Still and moving } \\
\text { images }\end{array}$ & $\begin{array}{l}\text { Colour, layout, style, lines, vectors, } \\
\text { perspectives/viewpoints, saliency, screen formats, } \\
\text { visual symbols, }\end{array}$ \\
\hline 3 & Audio & $\begin{array}{l}\text { Music, sound } \\
\text { effects, and noises }\end{array}$ & Volume, pitch, rhythm, silence, pause \\
\hline 4 & Gestural & $\begin{array}{l}\text { facial expression, } \\
\text { gestures, and body } \\
\text { movement }\end{array}$ & $\begin{array}{l}\text { Movement, speed, stillness, body position, body } \\
\text { language }\end{array}$ \\
\hline 5 & Spatial & $\begin{array}{l}\text { Layout and } \\
\text { organisation of } \\
\text { objects and space }\end{array}$ & $\begin{array}{l}\text { Proximity, direction, layout, position of and } \\
\text { organisation of objects in space. }\end{array}$ \\
\hline 6 & Tactile & $\begin{array}{l}\text { Touch, smell, and } \\
\text { taste }\end{array}$ & Interaction with objects \\
\hline
\end{tabular}

Drama allows students to be engaged in multimodality as they employ the images, audios, gestural, and other representational modes in the performance. Through its focus on multimodality, the range of modes of meaning-making and communication (audio, visual, linguistic, spatial, performative, etc.) extends language and literacy education beyond traditional literacy practices (New London Group 1996). In addition, drama provides a space for multimodal representations of meaning and draws on students' personal and cultural experiences in the creation of dramatically performed identity texts (Ntelioglou, 2011).

However, the circumstances of COVID-19 have changed the approach of drama performance and the biggest challenge is to maintain social distance (Prokosch, 2020). The limited size of the rehearsal and performance space, backstage for costume change were the challenges that were inevitable. Although the current students are digital natives who have developed new approaches to thinking and have the skills in using technology, certain scenes in drama are difficult to be performed remotely. Scenes that require hugging and holding hands require close contact and this brings a challenge to the actors. When drama has to be performed remotely, the actors are forced to perform alone in different locations without face-to-face interaction. Besides, The elements of stage performance and stagecraft skills will not be made to the fullest sense when the stage has gone virtually. This will definitely affect the performance.

Cope and Kalantzis (2009b) cautioned that 'meaning expressed in one mode cannot be directly and completely translated into another. The movie can never be the same as the novel. The image can never do the same thing as the description of a scene in language' ( $p$. 22). In multimodal texts or interactions, meaning is achieved through the use of a combination of modes which takes into account the interplay between them and different organisational 
principles that govern particular semiotic resources (Lyons, 2018). Therefore, different modes with their various affordances make meaning in different ways.

A drama in text is different from a drama on stage as well as a drama on the remote. This is why addressing multimodality is integral to drama courses. It will improve the students' repertoire of skills and critical thinking while dealing with complicated multimodal texts (Yi \& Choi, 2015). Mohd Jaafar and Thang (2020) found that the use of multiple representations (especially text and graphics) could improve students' comprehension when reading a text. The findings of a case study by Perry (2020) revealed that the conceptualisation and production of a transmedia storytelling project consisting of a short film, book and social media page were able to help students to engage with multiple modalities and develop various skills and competencies.

Appropriate teaching and learning practices can provide multimodal engagement for students that help them expand their repertoire of making sense of complex multimodal texts in a skilful and critical manner (Serafini, 2014). Linguistics modes (reading, writing, listening and speaking) as well as non-verbal modes (visual, audio, gestural, tactile and spatial) allow for differential modes of expression and communication in a remote drama performance and drama pedagogy has arguably always been multimodal, but perhaps less intentional about theorising of its practice (Ntelioglou, 2011). As research in the use of multimodality as a pedagogical tool in adapting Shakespeare's play for remote drama performance is not common in the local contexts, it is crucial to conduct this study to identify the modes of multimodality used by students and during remote drama performance.

\section{Methodology}

A case study design (Yin, 2014) was chosen to identify the multimodal engagement in this remote drama performance as it fulfils all the necessary requirements for the selected research design. Specifically, this study used a single case study method to enable a more indepth investigation, as well as a detailed description and understanding of multimodal participation in this project (Gustafsson, 2017).

In selecting the single case study to be examined, a purposive sampling method was used to four chosen cases. Adopting a deductive case study (Shanks, 2002), the first step was to decide the classical text to be adapted. The classical text "Macbeth" by William Shakespeare was selected for the students to adapt and perform. A total of four story adaptations of "Macbeth" was produced by the students. For the purpose of this study, only one story was chosen for analysis so that the description and analysis could be comprehensive and in-depth (Baškarada, 2014). Thus, "The Crown Game" was selected from the three other productions by the class as it met all the necessary conditions.

\section{Context of Study}

"Drama in English" is one of the compulsory courses for students of English language majoring in Teaching English as a Second Language (TESL) in an institute of teacher education in Malaysia. The course provides students suitable content and practical knowledge to use the English language competently through the study of plays while enhancing their communication skills and teamwork skills. The course lecturer, who was also one of the 
researchers, took the role of participant-observer in the class. This is important as the relationship with the class was multi-faceted; a researcher and lecturer.

There were 22 students consisting of three males and 19 females enrolled in the drama course. They were in an average of twenty years old and most of them did not have any experience in drama performance except a girl who was the school representative for drama competition. They took the drama course as one of the major courses in their second semester for fifteen weeks.

As the final course assessment required the students to stage a play, they had to resort to remote drama performance as online learning was the only choice during the COVID-19 pandemic. The concept of a short film was chosen because Perry (2020) highlighted that short film production could improve multimodality and other 21st century skills. Thus, incorporating multimodal platforms in the creation and production of a short film was important during this time.

\section{Research Procedure}

The teaching of drama texts was structured in three stages: pre-production, production, and post-production. The pre-production stage included introduction to the elements of plays, basic scriptwriting, storyboarding, film music, sound editing, film editing resources and digital tools in the course. Then, students read the synopsis and watched Shakespeare's plays on tragedy, comedy and history. They later studied "Macbeth" in detail by examining its elements in setting, plot, character, theme and conflict. After that, they wrote a script individually for an adaptation of "Macbeth" in the modern contexts. The course lecturer read 22 scripts at the initial stage and divided the students into four groups consisting of four or five members. Each group selected one script and planned a multimodal text using a storyboard for a short film.

The production stage was where the text was performed and produced. Students assigned among themselves the roles of directors, stage managers, costume designers, actors, and video editors. They met virtually in Google Meet for discussion, practice and rehearsal at their own time. As students engaged in the remote drama practice, they focused on linguistic modes (listening, speaking, reading, writing, intonation, stress, voice projecting), and gestural and spatial modes (physical movements, gestures and facial expressions).

Due to the restrictions imposed during the COVID-19 pandemic, students had to act out at individual homes in different locations in Malaysia. Most of them recorded their own acts with the aid of smart phones as they did not have other recording equipment. Then, they either sent their raw videos to the video editor in the group, or each of them did their own video in segments first, and then combined and produced the final video. In using digital applications and software, the students were involved in visual and audio modes (use of texts, images, music or sound effects), and other modes in the production of their short film.

The post-production stage took place at the end of the drama course when students uploaded their short films to YouTube Channel. They also wrote an individual reflective journal on the whole process of performing and producing the drama. 
DEVELOPMENT

Vol. 11, No. 1, 2022, E-ISSN: 2226-6348 @ 2022 HRMARS

\section{The Play: The Crown Game}

The play "The Crown Game" was produced by a group of five students. The story revolved around five princesses who competed with one another to become the queen by winning the Crown Game. Being the strongest princess, Merida believed she would win the game. However, the sneaky Snow White had already given the prince the love potion that made him fall in love only for her. In the forest, Merida met a witch who gave her 3 prophecies and gave her a poisonous apple to be eaten by Snow White so that the potion would become ineffective when she died. At the end of the game, Merida was dissatisfied that the prince still announced Snow White to be the queen though she was the first princess to arrive at the palace. Angered by the decision, Merida gave Snow White the poisonous apple that she ate and died. When the news reached the king and the queen, they were saddened but they proceeded to announce Merida to be the next queen. She was very happy but the prince refused to take her as the queen. Merida was frustrated and she killed herself with the sword, fulfilling the third prophecy of the witch. The short film could be accessed from YouTube link https://youtu.be/hsLFCN98NOY

\section{Data Collection Method}

The short film, playscript and reflective journals were among the sources of data for this study. They were submitted together in the Google Classroom. Students' reflective journals were collected to explore the use of multimodality in performing the drama remotely. This is an effective tool because it allows students to comprehend the thinking processes that go into grasping new concepts and abilities in a lesson (Colley, Bilics \& Lerch, 2012). Students wrote their reflections for the whole process of remote drama performance from the beginning of writing the playscript until they produced the final short film.

\section{Data Analysis Method}

In this study, data analysis and interpretation were based on a deductive method to conclusion drawing, in which meaning is taken from the data collected and evidence is logically formed based on the interpretation of the data (Gustafsson, 2017). A descriptive and interpretive technique was used to demonstrate the multimodal engagement found in the short film video uploaded to YouTube Channel by students. The interpretative researcher of a case study, according to Darke and Shanks (2002), is "presenting their interpretation of the interpretation of others, and the quality of analysis stems from the strength of the explanation of the phenomena based on the interpretation of data" (p. 118). Since the researcher is also the course lecturer, it is critical to acknowledge the researcher's background and the influence of the researcher in data collection and analysis procedures. Any question of biasness is acknowledged as the limitation of this study.

In order to ensure validity and reliability of this study, the analysis of the artefacts from the playscripts and short film was based on the framework of Cope and Kalantzis (2009a) as shown in Table 1 in the earlier section. After the researcher had completed analysing the data, an inter-rater was appointed. The inter-rater was a lecturer teaching a similar course in the institution but is not one of the researchers. After the second rater had completed analysing, a moderation session between the two raters was conducted to ensure the observed modes are accurate. 
Meanwhile, students' reflective journals were analysed thematically. All the reflective journals were analysed using Braun and Clarke's (2006) thematic analysis procedure. The same second rater, checked the themes for confirmation to ensure reliability and validity of the analysis.

\section{Ethical Issues}

Before the study was carried out, a consent form was given to each participant to obtain their permission. As this study utilised some images from the short films that involved the subjects, they were informed about the use of their images and their eyes were covered with a black box to protect their identity. Pseudonyms were also used in the discussion to maintain their anonymity and confidentiality.

\section{Findings and Discussion}

\section{Most Common Modes of Multimodality}

Based on the first research question that aimed to identify the most common modes of multimodality that students used in adapting Shakespeare's play into the remote drama performance, the playscripts and short film were analysed. Using the adapted framework in Table 1, the results showed that they were engaged in six multiple modes: linguistic, visual, audio, gestures, spatial, tactile, technical and digital.

\section{Linguistic Mode}

Linguistic mode refers to elements such as language, writing, speech, dialogue and vocabulary (Jewitt, 2008). Language is made up of written mode (reading and writing) and oral mode (listening and speaking). There is a usage of the alphabetic or written mode since they rely on words to create meaning. The linguistic mode was used the most throughout the process of producing the remote drama performance. During the pre-production stage, the students read the play "Macbeth" and wrote the playscript and storyboard for an adaptation of the play. The playscript used for drama consisted of a set of words written in monologues, dialogues, soliloquy, and stage directions while the storyboard consisted of words written for the descriptions, choice of images, audio and videos. During the production stage, the students engaged in oral mode (listening and speaking) when they practiced and rehearsed for the drama performance.

Based on the short film "The Crown Game", the written text in the video appeared in the beginning of the story with the title "The Crown Game". These words at the beginning of the video are meaningful to the audience to inform what to expect when watching the film. The word 'crown' symbolises the king, queen and throne. Besides, the word 'game' reflects the process of selecting the next king or queen is not easy and audiences are to expect to see challenges or problems.

Oral mode is the process of communication to convey or receive messages with the use of spoken words or live speech. Actors who deliver dialogues or monologues with the right tone of voice, inflection, accent and volume also demonstrate an understanding of how elements of voice, sound and volume can affect meaning production in a text (Perry, 2020). This mode of communication is highly used in staging or recording a drama. The lines from the playscript are full of oral mode as they are spoken by the characters during the drama performance. The 
lines could be spoken in the form of monologue, dialogues or soliloquy. Some speeches in dialogues are as follow:

"(Laughing) We need to sleep early. Tomorrow is a big day for us. (Excited) Prince Charming is going to pick his bride through the Crown Game." (Merida, Scene 1.)

"My princess, I can only tell you one from the three prophecies for free. (Chuckled) Two prophecies, for your first-born baby and three prophecies for your womb." (The witch, Scene 3.)

The oral mode can be enhanced through the voice projection, intonation, stress, and feelings portrayed by the characters which was indicated by the stage directions in brackets as shown in the script. In the examples provided, Merida was laughing as she was excited that the prince was going to choose the bride from the Crown Game while the witch chuckled wickedly in foretelling Merida's future.

\section{Visual Mode}

The visual mode refers to the characters and images that people see. Visuals created through the employment of various discursive strategies, e.g., adverbs, graphic verbs, details are more convincing and more memorable than abstract propositions (Tannen, 1989). In a live drama, the visual mode can be portrayed through the setting, costumes, and props. The three main settings of the story "The Crown Game" took place in the dormitory, palace, and forest. The drama began with the introduction of the characters. There were five main characters: Merida, Snow White, the prince, king and queen and three minor characters who were the princesses. As the characters were from the royal family, they wore the costumes appropriate for king, queen, prince and princess. The witch was typical with her black long gown. The props symbolic for a royal family were the crowns, rods and swords (Figure 1).

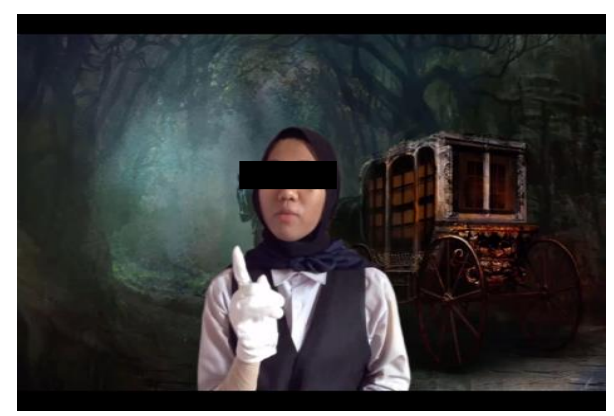

The prince in the forest

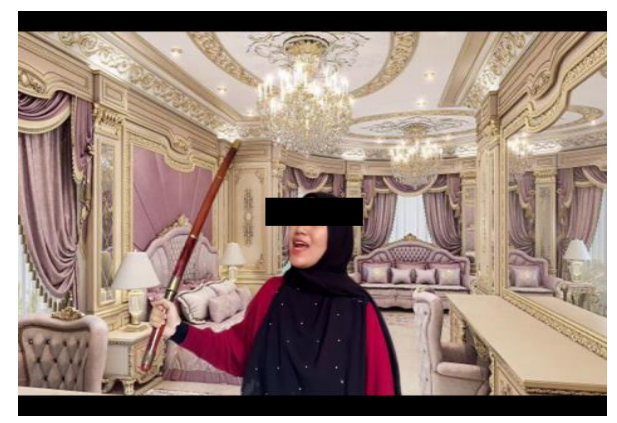

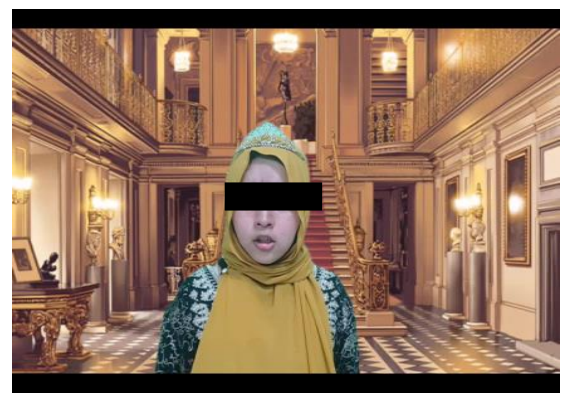

Merida in the palace

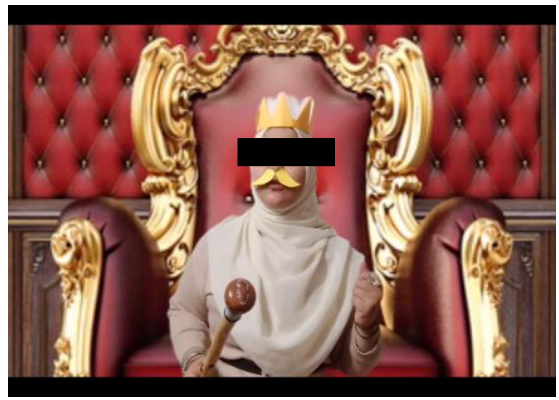


Figure 1. The visual modes of the characters, costumes and settings

When another representation, a picture for instance, is included in addition to the verbal input (linguistic mode), it makes the contents more comprehensible (Mohd Jaafar \& Thang, 2020). When the drama was performed in a digital form, the visual mode could be enhanced through colour, layout, style, size and perspective. Colour, especially the choice of colour palette or scheme, can reflect the mood or piece. For example, inside the Enchanted Forest, in scene 2, the use of colour was dark green. Dark green was associated with ambition, greed, and jealousy. The princesses were competing in the forest to become the bride of the prince. Here arose jealousy when Merida met the witch who told her about Snow White's plan of using the love potion.

In this play, a symbolic apple was used through its changes in size and appearance. Size is an estimate or measure of something's dimensions. It can be measured in the size of big or small. In the video, the size of the apple was emphasised as it slowly became bigger (Figure 2). It was used as a symbolic object by Merida to achieve her goal. The appearance of the apple changed when it slowly became rotten to indicate Snow White's dream of becoming the queen was destroyed when she ate the fruit and died (Figure 3).

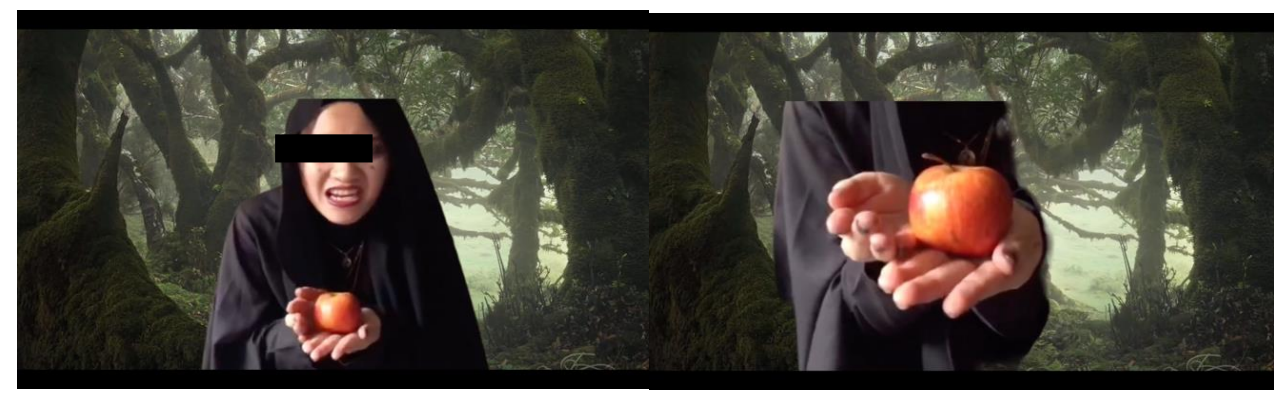

Figure 2. The visual mode of the changing size of the apple

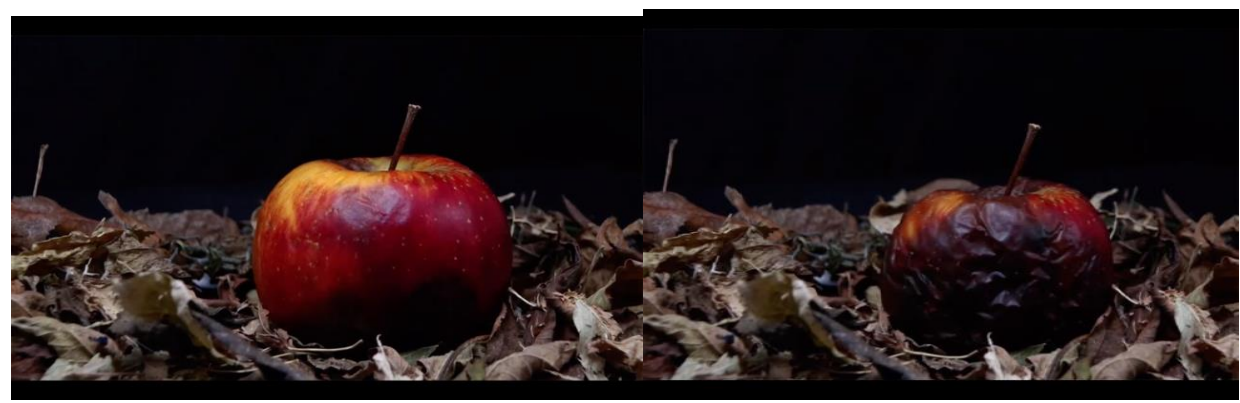

Figure 3. The visual mode of the changing appearance of the apple

\section{Audio Mode}

Audio mode includes music, ambient sounds, noises, alerts (representing meaning to another); hearing, listening (representing meaning to oneself). The music gives meaning to a character's actions or translates their thoughts and it creates emotion. In the play, the music used was "Connected, Barbie and The Diamond Castle" when the princesses sang along in the dormitory in Scene 1. 
DEVELOPMENT

Vol. 11, No. 1, 2022, E-ISSN: 2226-6348 @ 2022 HRMARS

The soundtrack was used to emphasise the psychological states of the characters, as well as deliver a collective emotional tone or mood to the viewer. The soundtrack "Suspicious" was used when the witch told Merida about a great prophecy.

In drama, narration is important to inform the audience specific plot points they need to know. It's a great way to let them inside the minds of the characters as well as help to set the scene. The narration in the story was short in common, for example, "Suddenly, the princesses started to boast about their beauty and speciality" (Scene 1). This narration set the scene that the princesses boasted about themselves as they thought their beauty and speciality would make them the queen later.

\section{Gestural Mode}

Gesture is a movement of part of the body, especially a hand or the head, to express an idea or meaning. The gestural mode of communication allows actors to communicate meaning through facial expressions, hand gestures, body language, and interaction between people (Arola, 2014).

In the short film, the princesses Aurora and Jasmine used their hand movements to convey the meaning of the lyrics of the song. For example, the gestures when the princess Jasmine and princess Aurora sang the song "Barbie and The Diamond Castle" with the lyric "you hear me" could be seen when a hand was placed on the ear and the other hand pointing to the audience to indicate "you". Meanwhile, the lyric "protected" was shown where they put their hands closer to them.

Facial expressions are a form of nonverbal communication. Based on Figure 4, we can detect facial expressions used from both of these characters. They show the facial expression of desire to be the next queen and enthusiasm to beat each other in any way to win the game.

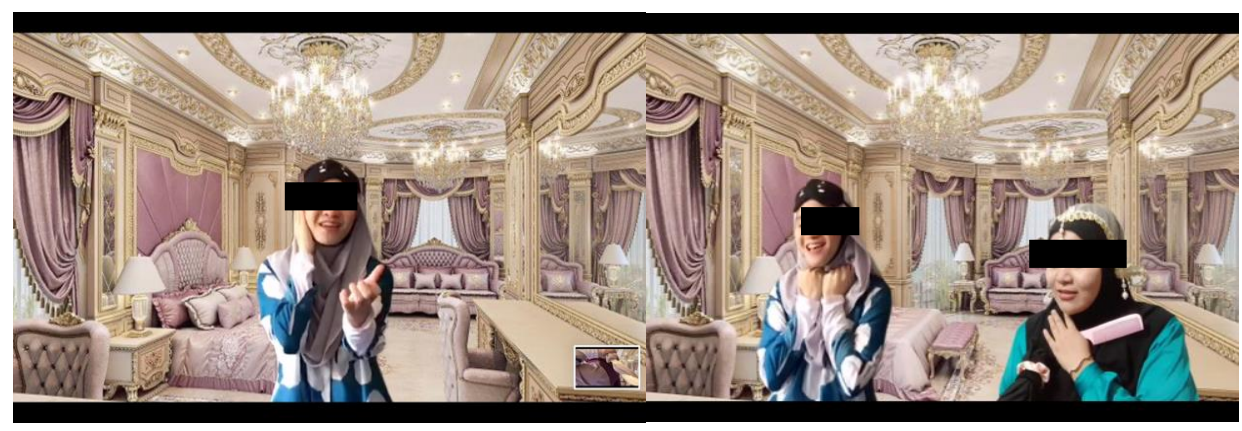

Figure 4. The gestural mode through gestures and facial expressions

Body language is also a non-verbal communication that relies on body movements to convey meaning. Figure 5 shows the two main characters projected very good body language when the prince announced that the winner of the game was Snow White. Snow White smiled widely and shrugged her shoulders to show her aloofness or indifference while Merida's clenched her fist to show her anger and dissatisfaction on hearing the result. 


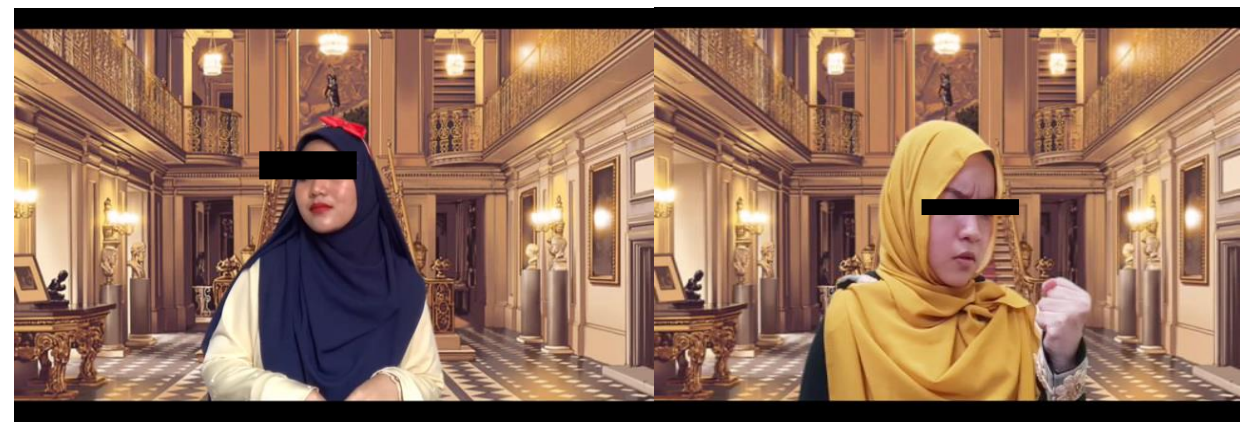

Figure 5. The gestural mode through body language

\section{Spatial Mode}

Spatial mode includes physical arrangement such as organisation, position, proximity, spacing, direction and distance of elements in a text. The position of the video was when the characters were placed at the centre of the video so that the audiences could see them clearly.

The text organisation includes the position of the text, its size and also the font that is used. At the beginning and the end of the video, the texts were placed at the centre. The size was big enough and the fonts were suitable for the video as the audiences could see them clearly. Text speed occurs when the speed of the appearance of the text is not too slow or too fast. At the end of the video, there was a credit part which showed the list of the names of the cast who were involved in making the video. The speed of the text at the credit part of the video was not too slow or too fast, giving the audiences enough time to read it (Figure 6).

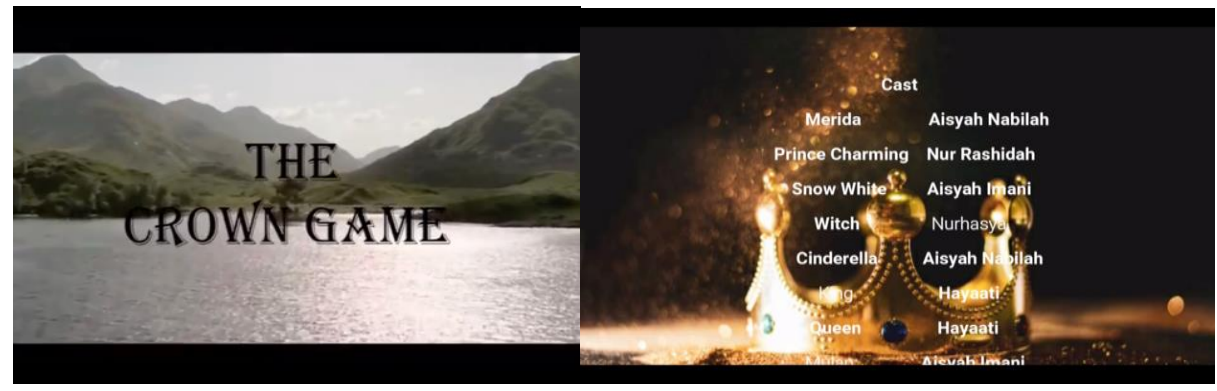

Figure 6. The spatial mode through the font size and text speed

\section{Tactile Mode}

Tactile mode is the representation of one's bodily sensations through touching, smelling and tasting. The forms of tactile representation include kinaesthesia, physical contact, grasp, manipulable objects, eating, and aromas (Cope \& Kalantzis, 2009a). It is impossible to portray tactile mode in the production of short film as it needs to show the feelings or representations to others which 'touch' them bodily. It could be felt during the practice and rehearsal and the examples of tactile mode were:

Touch: Snow White took the apple that was given by Merida. (Scene 4)

Taste: Snow White ate the poisonous apple and died. (Scene 4)

In accordance to Perry's (2020) study on the use of transmedia storytelling project as a pedagogical tool for multimodal engagement, the analysis above highlights the students 
DEVELOPMENT

Vol. 11, No. 1, 2022, E-ISSN: 2226-6348 @ 2022 HRMARS

were engaged with linguistic, visual, audio, gestural, spatial, and tactile modes through their selection and representation of meanings in performing and presenting their remote drama performance. They participated actively in conceptualising, designing and producing multiple modes of meanings through the short film.

\section{Students' Engagement in Learning Through Multimodality}

This study also sought to find out the students' engagement of learning through multimodality by performing Shakespeare's play remotely. To answer research question two, students' reflective journals were analysed thematically using Braun and Clarke's (2006) framework. The analysis found three main themes, namely learning technical skills and technological skills and learning through cooperation.

\section{Learning Technical Skills}

To perform the drama remotely, the students engaged actively with their technical skills especially during video shooting. As they needed to perform drama at individual homes, some of them found it difficult to do it alone. Some had problems in acting out the characters as there was no one around them to help while others had the problems in finding suitable places and lighting to do the shooting. However, they were able to find the ways to overcome the problems.

One of the things that I learned when recording is that we have to find a suitable place, so that there are no sources that can interrupt my recording process. That is why I took an empty room so that nobody could disturb me. (Student AM)

The challenge that I faced during completing this task was finding a place to shoot the play. It was challenging because I did not have a suitable place to shoot due to the limited area in my house compound, because my neighbour's houses are near to each other. So, I thought about the solution and decided to just shoot in my room and add a background effect later. (Student Al)

\section{Learning Technological Skills}

Video editing is a tedious work requiring students to use the software to assemble the footage, sort the clips, arrange in a timeline, cut and trim the clips, add the audios, titles, transitions, animations, and finally the product. Recognising the need for technology skills in video editing, the students agreed that doing remote drama enabled them to learn more about it.

I was able to learn how to edit videos and upload them on YouTube in the correct format but editing the videos is the most challenging part because we need to synchronise all the videos, music and background images in a single video. (Student Al)

I learned how to edit videos creatively. It was difficult at first, but l've grown a lot and it's no longer a challenge for me. Now I can compare editing applications and determine which is the easiest and most easy to use. (Student NS) 
DEVELOPMENT

Vol. 11, No. 1, 2022, E-ISSN: 2226-6348 @ 2022 HRMARS

\section{Learning Through Cooperation}

It was found that students acknowledge the value of working in groups during the remote drama performance. Though the students faced a lot of challenges in shooting and editing the videos, the cooperation among the group members had enabled them to overcome those problems successfully.

From the beginning until the end of this task, the most important element that I discovered was the power of teamwork in producing a great play, especially through an online platform. It was really challenging, but everything was possible with cooperation from each member. (Student Al)

The process of editing the film is done smoothly as each one of us contributes our effort to make sure that we can get the best result. (Student NR)

For Stein (2008), the "move from face-to-face multimodal interaction with a living, breathing audience ... to the solitary confrontation with a blank page" leads to a "profound loss" ( $p$. 62). During video shooting, the students expressed their difficulties in finding the suitable place and lighting while doing it alone. They also had the problems in finding the best applications for video editing. However, the teamwork and cooperation had helped them in overcoming these challenges and they were able to produce the short film. This shows that when students are more engaged, they learn more.

Drama provided a space for multimodal representations of meaning and drew on students' personal and cultural experiences during the process which enables students to explore their linguistic and social performances despite challenges (Ntelioglou, 2011). The students' engagement with the multimodality in remote drama performance showed that they had the ability to view multimodal texts critically and to make multimodal representations effectively (Lim, 2018). This study yields the results and findings that deem the importance of multimodality approach in remote drama performance.

The multimodal engagement of remote drama implies that reception (reading the drama texts) and production (performance) of drama are two sides of the same coin. It bridges the divide between literature learning and its writing, and has potential for the selfempowerment of learners (Newfield \& D'abdon, 2015). Through multimodality, student learning was evident when they learnt technical and technological skills and the cooperation enabled them to overcome the challenges.

It is therefore vital that educators have the knowledge of and access to suitable theoretical, curricular and pedagogical frameworks that would enable them to provide an engaging multimodal learning experience for their students (Lim \& Tan, 2018; Serafini, 2014). The use of remote drama performance as formative project-based assessment for a course also enables students to have an active and immersive engagement with multiple modes of meaning instead of merely being passive consumers of a multimodal text or ensemble (Perry, 2020). In the future it is hoped that pedagogies in multimodality should be widely conducted and focus on character building. 
DEVELOPMENT

Vol. 11 , No. 1, 2022, E-ISSN: 2226-6348 @ 2022 HRMARS

\section{Limitation of the study}

This study was only conducted on one group of pre-service teachers from the an institute of teacher education located in the state of Johor. Due to the limited sample size and the locality of the schools, the results cannot be generalised to a wider scope.

\section{Conclusion}

The findings indicated that there were six most common multiple modes used by the student, namely, linguistic, visual, audio, gestural, spatial, and tactile. Besides, the thematic analysis also highlighted students' engagement in learning technical and technological skills as well as cooperation during the remote drama process.

Due to COVID-19, drama is no longer performed live but remotely, so there is a need to revise the techniques and contents of the drama course. The potentials of integrating new technology in filmmaking remotely can be explored. The implication is for teachers, teacher educators, curriculum designers, materials developers, examiners, scholars, and researchers to use multimodality as a pedagogical tool in the drama course.

Using multimodal platforms in remote drama performance is believed to be a great idea and needs to be explored extensively. It is recommended for the future researches to do a comparative study between live drama and remote drama or to explore remote drama in an ethnography study.

\section{Contribution}

The findings from this study paves the ways for revising the course contents for the drama pedagogy in higher education and teacher education to include multimodality through the integration of technology. It also provides insights for future research into the use of multimodal pedagogical tools in the field of English language especially for remote drama courses.

The theoretical framework employed in this study shows that multimodality used in remote drama allows students to engage in meaning-making and communication through visual, audios, linguistic, gestural, and other representational modes in the performance. Through it was conducted in an institute of teacher education, the findings extends language and literacy education beyond traditional literacy practices. Thus, it provides a new pedagogical instructional tool for the pre-service teachers, school teachers and teacher educators.

\section{References}

Arola, K., Sheppard, J., \& Ball, C. E. (2014). Writer/Designer: A guide to making multimodal projects. Boston, USA: Bedford /St Martins.

Baškarada, S. (2014). Qualitative case study guidelines. The Qualitative Report, 19(40), 1-25.

Bezemer, J. (2012). What is multimodality. UCL Institute of Education. Retrieved https://mode.ioe.ac.uk/2012/02/16/what-is-multimodality/

Braun, V., \& Clarke, V. (2006). Using thematic analysis in psychology. Qualitative Research in Psychology, 3(2), 77-101.

Colley, B., Bilics, A., \& Lerch, C. (2012). Reflection: A key component to thinking critically. The Canadian Journal for the Scholarship of Teaching and Learning, 3, 1-19.

Cope, B., \& Kalantzis, M. (2009a). Multiliteracies: New literacies, new learning. Pedagogies, 
DEVELOPMENT

Vol. 11 , No. 1, 2022, E-ISSN: 2226-6348 @ 2022 HRMARS

4(3), 164-195. DOI: 10.1080/15544800903076044

Cope, B., \& Kalantzis, M. (2009b). A grammar of multimodality. The International Journal of Learning, 16(2), 361-426. DOI: 10.18848/1447-9494/CGP/v16i02/46137

Costa, K. (2016). Gesturing Shakespeare, or reading with the whole body. Revised. Shakespeare Works When Shakespeare Plays. UC Davis School of Education.

Darke, P., \& Shanks, G. (2002). Case Study Research. In K. Williamson, Research methods for students, academics and professionals: Information management and systems. 111125. (2nd ed.). Centre for Information Studies.

Gustafsson, J. (2017). Single case studies vs multiple case studies: A comparative study. Retrieved http://www.diva-portal.org/smash/get/diva2:1064378/FULLTEXT01.pdf

Hafner, C. A. (2015). Remix culture and English language teaching: The expression of learner voice in digital multimodal compositions. TESOL Quarterly, 49(3), 486-509.

Hagan, U. (1991). A challenge for the actor. New Youk, USA: Charles Scribner's Sons.

Jewitt, C. (2008). Multimodality and literacy in school classrooms. Review of Research in Education, 32, 241-267. DOI: 10.3102/0091732X07310586.

Kaminski, A. (2019). Young learners' engagement with multimodal texts. ELT Journal. 73(2), 175-185. DOI: https://doi.org/10.1093/elt/ccy060

Lim, F. V. (2018). Developing a systemic functional approach to teach multimodal literacy. Functional Linguistics, 5(13), 1-17.

Lim, F., \& Tan, S. (2018). Developing multimodal literacy through teaching the critical viewing of films in Singapore. Journal of Adolescent \& Adult Literacy, 62(1), 291- 300. DOI: https://doi.org/10.1002/jaal.882

Luh, A. (2019). Using drama in EFL classroom. Journal of English Teaching, 5(2), 125-134. DOI: http://dx.doi.org/10.33541/jet.v5i2.1066

Lyons, A. (2018) Combining modes. In: Cotter, C. \& D. Perrin (eds.) Routledge Handbook of Language and Media (pp. 296-308). London, UK: Routledge.

Mohd Jaafar, N., \& Thang, S.M. (2020). Processing of a multi-representational Science passage by ESL learners. GEMA Online Journal of Language Studies, 20(4), 18-28. DOI: http://doi.org/10.17576/gema-2020-2004-02

Murphy, S., Culpeper, J., Gillings, M., \& Pace-Sigge, M. (2020). What do students find difficult when they read Shakespeare? Problems and solutions. Language and Literature, 29(3), 302-326.

New London Group. (1996). A pedagogy of multiliteracies: Designing social futures. Harvard Educational Review, 66(1), 60-92.

Newfield, D., \& D'abdon, R. (2015). Reconceptualising poetry as a multimodality genre. TESOL Quarterly, 49(3), 510-532. DOI: https://doi.org/10.1002/tesq.239

Nicholson, H. (2011). Theatre, education and performance: the map and the story. New Your, USA: Palgrave Macmillan.

Ntelioglou, B. Y. (2011). "But why do I have to take this class?" The mandatory drama-ESL lass and multiliteracies pedagogy. Research in Drama Education: The Journal of Applied Theatre and Performance, 16(4), 595-615.

DOI: https://doi.org/10.1080/13569783.2011.617108

Olive, S. (2015). Shakespeare valued: Education policy and pedagogy 1989-2009. Bristol, UK: Intellect Books.

O'Neill, C. (2018). Context or essence: The place of drama in the curriculum. In C. Day \& J.L. Norman (Eds.). Issues in Educational Drama (1st ed.). Issues in educational drama (pp. 25-32). New Your, USA: Routledge. 


\section{DEVELOPMENT}

Vol. 11, No. 1, 2022, E-ISSN: 2226-6348 @ 2022 HRMARS

Perry, M.S. (2020). Multimodal engagement through a transmedia storytelling project for undergraduate students. GEMA Online Journal of Language Studies, 20(3), 19-40.

Prokosch, M. (2020). The challenges of COVID-19 theater productions. Saint Mary's University of Minnesota. Retrieved from https://cardinal.smumn.edu/the-challenges-of-covid-19theater-productions/

Serafini, F. (2014). Reading the visual: An introduction to teaching multimodal literacy. New York: Teachers College Press.

Shanks, G. (2002). Guidelines for conducting positivist case study research in information system. Australasian Journal of Information Systems, 10(1), 76-85. DOI: 10.3127/ajis.v10i1.448

Stein, P. (2008). Multimodal pedagogies in diverse classrooms: Representation, rights and resources. New Your, USA: Routledge.

Tannen, D. (1989). Talking voices: Repetition, dialogue, and imagery in conversational discourse. Cambridge, UK: Cambridge University Press.

Trujillo, M. L. (2021). Theatre during COVID-19: Perceptions of high school students and teachers. Master of Education in Teaching and Learning, 44. https://digitalcommons.acu.edu/metl/44

Vungthong, S., Djonov, E., \& Torr, J. (2017). Images as a resource for supporting vocabulary learning: A multimodal analysis of Thai EFL tablet apps for primary school children. TESOL Quarterly, 51(1), 32-58. DOI: https://doi.org/10.1002/tesq.274

Yi, Y., \& Choi, J. (2015). Teachers' views of multimodal practices in K-12 classrooms: Voices from teachers in the United States. TESOL Quarterly, 49(4), 838-847. http://dx.doi.org/10.1002/tesq.219

Yin, R. K. (2014). Case study research design and methods (5th ed.). California, USA: Sage. 